УДК [811.111+811.14’06]'373.611

DOI https://doi.org/10.26661/2414-9594-2020-2-20

\title{
КОЛЬОРОНАЗВИ В НОМІНАТИВНІЙ СТРУКТУРІ АНГЛІЙСЬКИХ ТА УКРАЇНСЬКИХ КОМПОЗИТІВ
}

\author{
Філатова К. О. \\ кандидат філологічних наук, \\ старший викладач кафедри перекладу \\ Приазовський державний технічний університет \\ вул. Університетська, 7, Маріуполь, Донеиька область, Україна \\ orcid.org/0000-0002-9437-4382 \\ katerinaf19853008@gmai.com
}

\begin{abstract}
Ключові слова: базисні пропозиціональні схеми, кольороназви, номінативні одиниці, домен, когнітивні засади, символьне значення, номінативна структура.
\end{abstract}

Устаттіописанотрьохетапнупроцедурупорівняльноголінгвокогнітивного аналізу композитів із кольороназвами в англійській та українській мовах. Зокрема, надано перелік операцій, застосованих на кожному етапі лінгвокогнітивного аналізу колоративних композитів двох мов. У статті узагальнено результати лінгвокогнітивного аналізу англійських композитів із кольороназвами black, white, red, green, yellow, blue, brown, gray, purple, pink, orange та українських композитів із колоративами білий, чорний, червоний, зелений, жовтий, синій, блакитний, голубий, коричневий, сірий, рожевий.

У дослідженні детально описано послідовні кроки, виконані під час порівняльного аналізу композитів 3 основними колоративами в англійській та українській мовах. Серед них: визначено типовість таких номінативних одиниць для складу досліджуваних мов; 3'ясовано схожість і розбіжності у промінантності кольороконцептів у складі композитів англійської та української мов, що дозволило визначити особливості кольорів у концептуальних картинах світу двох народів; установлено схожість та відмінності в доменах предметних сутностей, наділених колірною ознакою; порівняно залученість базисних пропозиціональних схем до номінативних процесів англійської та української мов; установлено типи номінативних процесів, характерних для творення композитів досліджуваних мов; 3'ясовано спільні та ідіоетнічні когнітивні засади словотвору двох мов; визначено схожість та відмінності в символьних значеннях кольороконцептів у складі номінативної структури композитів англійської та української мов, які віддзеркалюють особливості англійськомовних та україномовних картин світу.

У висновках продемонстровано результати порівняльного лінгвокогнітивного аналізу композитів англійської мови з кольороназвами black, white, red, green, yellow, blue, brown, gray, purple, pink, orange та композитів української мови із колоративами білий, чорний, червоний, зелений, жовтий, синій, блакитний, голубий, коричневий, сірий, рожевий i, відповідно, визначено спільні та відмінні риси, характерні для словотворчих процесів досліджуваних мов. У висновках також зазначено перспективу подальших розвідок у цьому напрямку. 


\title{
COLOR-TERMS IN NOMINATIVE STRUCTURE OF ENGLISH AND UKRAINIAN COMPOUNDS
}

\author{
Filatova K. O. \\ Candidate of Philological Sciences, \\ Senior Lecturer at the Department of Translation \\ Pryazovskyi State Technical University \\ Universytetska str., 7, Mariupol, Donetsk region, Ukraine \\ orcid.org/0000-0002-9437-4382 \\ katerinaf19853008@gmai.com
}

Key words: basic propositional schemas, colors, nominative units, domain, cognitive principles, symbolic meaning, nominative structure.
The article describes the three-stage procedure of comparative cognitive linguistic analysis of compounds with color-terms in English and Ukrainian. In particular, the research provides the list of steps to be taken on each stage of cognitive linguistic analysis of compounds with color-terms of two languages. The article generalizes the results of cognitive linguistic analysis of English compounds with black, white, red, green, yellow, blue, brown, grey, purple, pink, orange color-terms and the results of cognitive linguistic analysis of Ukrainian compounds with білий, чорний, червоний, зелений, жовтий, синій, блакитний, голубий, коричневий, сірий, рожевий color-terms.

The research also describes the consecutive steps of comparative analysis of compounds with color-terms in English and Ukrainian. The compared aspects are the following: determination of the characteristic features of studied nominative units of two languages; identification of similarities and differences in salience of different basic color-concepts in the nominative structure of English and Ukrainian compounds, that allowed to determine the peculiarities of colors in conceptual models of world of two ethnic communities; determination of similarities and differences in salience of the ontological domains of «colored» objects; comparison of salience of different basic propositional schemas applied in naming processes in English and Ukrainian; identification of types of naming processes applied in coining of English and Ukrainian compounds thus pinpointing common and idioethnic cognitive principles of word-formation of studied languages; determination of similarities and differences in the foundations of symbolic meanings developed by different colors in nominative structure of English and Ukrainian compounds that reflect the peculiarities of English speaking and Ukrainian speaking models of world.

The conclusions summarize the results of comparative cognitive linguistic analysis of English compounds with black, white, red, green, yellow, blue, brown, gray, purple, pink, orange color-terms and Ukrainian compounds with білий, чорний, червоний, зелений, жовтий, синій, блакитний, голубий, коричневий, сірий, рожевий color-terms thus the research determines the similarities and differences in naming processes of studied languages and presents common and idioethnic features of two communities. The conclusions also provide the perspective of further cognitive linguistic research.
Постановка проблеми. Колористика завжди цікавила широкий прошарок дослідників по всьому світу, спонукаючи їх вивчати кольори та їх вплив на життя та світосприйняття людини [22; $23 ; 24 ; 25 ; 26 ; 27 ; 28]$. Щодо кількості кольороназв у різних мовах світу й досі точаться дискусії, оскільки 3 плином часу з'являються як нові кольори, так і нові відтінки й тони. Не оминула тема кольоронайменувань і лінгвістів, які впритул досліджували кольороконцепти в різних мовах світу $[12 ; 11 ; 2 ; 16 ; 21]$, й зокрема в англійській $[11 ; 2 ; 3]$ та українській $[14 ; 6 ; 7 ; 1 ; 13]$.

Однак кольороназви цікавили вчених не тільки як самостійні одиниці, а і як компоненти стійких сполучень, й зокрема композитів $[4 ; 5 ; 15]$. Отже, актуальним постає питання щодо альтернативних 
способів творення номінативних одиниць, до складу яких входить та чи інша кольороназва, а особливо в неблизькоспоріднених мовах.

Метою дослідження $є$ знаходження спільних та відмінних рис у номінативних процесах творення колоративних композитів англійської та української мов. Наше дослідження націлено на виконання таких завдань: 1) застосування розробленої методики лінгвокогнітивного аналізу композитів із кольороназвами в неблизькоспоріднених мовах; 2) узагальнення відомостей щодо аналізу композитів 3 основними кольороназвами в англійській та українській мовах; 3) порівняння всіх груп композитів англійської та української мов 3 основними кольороназвами.

Об'єктом дослідження $є$ композити 3 кольороназвами в англійській та українській мовах. Предмет дослідження - лінгвокогнітивне підгрунтя формування композитів із кольороназвами в досліджуваних мовах.

Виклад основного матеріалу дослідження. Процедура порівняльного лінгвокогнітивного аналізу композитів із кольороназвами в англійській та українській мовах складається із трьох етапів, кожен 3 яких має відповідні кроки. На першому етапі лінгвокогнітивного аналізу композитів із кольороназвами проводиться аналіз композитів 3 окремою кольороназвою в досліджуваній мові, на другому - аналіз композитів зі всіма основними кольороназвами в досліджуваній мові, на третьому етапі - порівнюються результати аналізу композитів зі всіма кольороназвами в досліджуваних мовах [17, с. 74; 20, с. 94].

Перший та другий етапи лінгвокогнітивного аналізу колоративних композитів англійської $[17$, с. $84-127 ; 18]$ та української $[17$, с. $127-155$; 19] мов детально викладено в зазначених публікаціях.

Наше дослідження зосереджує свою увагу на третьому - порівняльному - етапі лінгвокогнітивного аналізу композитів із кольороназвами в англійській та українській мовах. У нашому дослідженні ми провели такий аналіз, що дало нам можливість: визначити типовість таких лексичних одиниць для складу досліджуваних мов; 3'ясувати схожість і розбіжності в промінантності кольороконцептів у складі композитів двох мов, відповідно, визначити особливості кольорів у концептуальних картинах світу двох народів; установити схожість та відмінності в доменах предметних сутностей, наділених колірною ознакою; порівняти залученість базисних пропозиціональних схем до номінативних процесів англійської та української мов; установити тип номінативних процесів, характерних для творення композитів досліджуваних мов; з'ясувати спільні та ідіоетнічні когнітивні засади словотвору двох мов; визначити схожість та відмінності в символьних значеннях кольороконцептів у складі номінативної структури композитів англійської та української мов, які віддзеркалюють особливості англійськомовних та україномовних картин світу $[17$, с. $26-27,78]$.

Композити 3 основними кольороназвами було відібрано із приблизно однакових за обсягом лексикографічних джерел англійської (MerriamWebster's Collegiate Dictionary) та української (Великий тлумачний словник сучасної украӥнської мови) мов. Такі номінативні одиниці виявились більш уживаними в англійській мові (740 одиниць) та вдвічі менш уживаними в українській мові (393 одиниці).

За промінантністю кольорів у складі композитів досліджуваних мов кольори було розподілено на центральні та периферійні. В англійській та українській мовах центральними, найчастіше уживаними кольороконцептами виявились «чорний», «білий» та «червоний». «Жовтий» в українські мові знаходиться на периферії-1, а в англійській - на периферії-2, оскільки є менш активним у цій мові. На периферії-1 в англійські мові знаходиться «зелений». Периферію-2 номінативного поля композитів в англійській та українській мовах займає «синій (блакитний, голубий)» колір, який знаходиться на четвертій позиції за ступенем своєї промінантності в англійській мові та є втричі менш уживаним в українській мові. Можна припустити, що промінантність «синього» в англійській мові та «жовтого» в українській мові є віддзеркаленням забарвлення природного середовища: в одному випадку - моря і неба, в іншому - сонця і степу. Однакову активність у двох мовах показує «сірий» колір, віднесений до Периферії-2. «Коричневий» і «рожевий» кольори займають у різних мовах місця на Периферії-2 та Периферії-3, оскільки демонструють різний ступінь промінантності.

У результаті дослідження було виявлено, що однакові кольори можуть демонструвати більшу частотність у номінативних процесах англійської мови в порівняні з українською, та навпаки. У номінаціях української мови превалюють «чорний», «жовтий», «сірий» та «рожевий», а в номінаціях англійської - «червоний», «зелений», «синій (блакитний, голубий)» та «коричневий» кольори.

Композити 3 кольороназвами в англійській та українській мовах позначають вісім онтологічних доменів: ЛЮДИНА, ТВАРИНА, РОСЛИНА, ПРИРОДНИЙ ОБ'ЄКТ, МІСЦЕ (ТЕРИТОРІЯ), АРТЕФАКТ, ОДЯГ та ЇЖА. Як показало дослідження, композити 3 кольороназвами найчастіше називають тварину, рослину і людину як в англійській, так і в українській мовах. Дослідження також дозволило виявити домінування певного 
кольору в онтологічних доменах номінативного поля англійських та українських композитів. В англійській та українській мовах у номінаціях онтологічних доменів превалюють такі кольори: червона (англ.), чорна (укр.) - ТВАРИНА; чорна (англ., укр.) - ЛЮДИНА; червона (англ.), чорна (укр.) - РОСЛИНА; білий, синій (англ.), зелений, червоний (укр.) - АРТЕФАКТ; червоний (англ.), чорний, білий (укр.) - ПРИРОДНИЙ ОБ'ЄКТ; чорний (англ., укр.) - ОДЯГ; червона (англ.), чорна (укр.) - ЇЖА; зелене (англ.), чорне (укр.) - МІСЦЕ (ТЕРИТОРІЯ).

Як свідчать наші попередні дослідження [17, с. 84-127, с. 127-155; 18; 19], композити 3 кольороназвами англійської та української мов утворюються на різних кроках концептуальної деривації. «Композити, утворені на першому кроці, мають ономасіологічну модель, базовану на квалітативній пропозиціональній схемі «Х (базис) $€$ ТАКИЙ-колір (ознака)». Значення цих композитів $є$ прямим: вони позначають певну онтологічну сутність, наділену тим чи іншим кольором. Пропозиціональна схема «Х є ТАКИЙ-колір» може брати участь у подальшій концептуальній деривації як основа метонімічних та/або метафоричних процесів, у результаті яких перетворюється значення композита, супроводжуване зазвичай i перетвореннями його форми» [17, с. 186].

Найбільша кількість композитів із кольороназвами англійської мови утворюється на першому кроці деривації, вони мають прямі значення. В українській мові найбільша кількість композитів утворюється шляхом метонімічних зсувів. Метафоричні процеси утворення композитів із кольороназвами однаково характерні як для англійської, так і для української мов. Утворення композитів шляхом змішаних зсувів в обох мовах незначне.

«Метонімічні зсуви відбуваються на підставі базисних пропозиціональних схем: партитивності, каузації, власності, контактної дії, інклюзивності, локативності, темпоральності» $[8 ; 9 ; 10]$. У результаті дослідження виявлено, що партитивна схема найчастіше вживається в метонімічних зсувах під час творення композитів із кольороназвами обох мов. Високий ступінь залученості до номінативних процесів англійської та української мов демонструє також схема власності. Досить часто задіяною у творенні композитів англійської мови є також схема каузації та контактної дії, що практично не характерно для номінативних процесів української мови, в результаті яких таким способом утворюється незначна кількість композитів. В українській мові також часто в номінативних процесах задіяна схема інклюзивності на відміну від англійської мови. Буттєві схеми локативності й темпоральності є найменш задіяними в дериваційних процесах двох мов.
Метафоричні зсуви відбуваються на підставі базисної пропозиціональної схеми подібності. Такі зсуви досить часто відбуваються в англійські мові у творенні композитів із кольороназвами, що $\epsilon$ менш характерним для української мови.

Проаналізовані дериваційні процеси англійської та української мов засвідчують, що найбільша кількість композитів із переносним значенням у цих мовах утворюється на другому дериваційному кроці. На третьому та четвертому кроках деривації утворюється незначна кількість композитів із кольоронайменуваннями в обох мовах, які мають переносне значення.

Дослідження показало, що композити із кольороназвами, які мають символьне значення, утворене від самого кольору, були виявлені в англійській та українській мовах приблизно в однаковій кількості. Однак кольороназви у своєму символьному значенні у складі композитів англійської та української мов демонструють різний ступінь уживаності. Так, найбільш уживаними кольороназвами із символьним значенням у складі композитів двох мов $є$ «чорний», «білий» та «червоний»; в англійській мові можна також виділити «синій (блакитний, голубий)».

Висновки. У результаті порівняльного аналізу англійських та українських композитів із кольороназвами було виявлено їхні спільні та відмінні риси. Найчастіше вживаними в номінативних процесах обох мов виявились кольороконцепти чорний, білий та червоний за значного домінування чорного в англійській та українській мовах. Що стосується участі інших кольороконцептів у номінації композитів, то можна зазначити, що в англійській мові активно задіяні синій (блакитний, голубий), зелений та коричневий кольори, а в українській мові - жовтий, сірий та рожевий. Фіолетовий та оранжевий кольори не представлені у складі композитів української мови.

Аналізовані композити англійської та української мов представляють вісім онтологічних доменів: ЛЮДИНА, ТВАРИНА, РОСЛИНА, ПРИРОДНИЙ ОБ'СКТ, МІСЦЕ/ТЕРИТОРІЯ, АРТЕФАКТ, ОДЯГ та ЇЖА. В англійській мові найбільшою кількістю композитів позначений домен ТВАРИНА, в українській мові - домени ТВАРИНА та ЛЮДИНА. Композити 3 кольоронайменуваннями чорний, червоний та білий переважають за кількістю в усіх доменах.

Як показало дослідження, утворення композитів англійської та української мов відбувається на різних дериваційних кроках. В англійській мові найбільше композитів утворюється на першому кроці деривації, вони мають пряме значення. В українській мові найбільша кількість композитів утворюється на другому дериваційному кроці шляхом метонімії та має при цьому переносне значення. Композитів, утворених метонімічним 
шляхом, в англійській мові трохи менше. Метафоричні та комплексні зсуви відбуваються в обох мовах в окремих випадках. Метонімічні зсуви у двох мовах найчастіше відбуваються на основі базисних пропозиціональних схем партитивності та власності, метафоричні зсуви - на підставі базисної пропозиціональної схеми подібності, в українській мові, в поодиноких випадках - базисної пропозиціональної схеми схожості/аналогії.
Композитів із кольороназвою - символьною ознакою в українській мові за кількістю більше, аніж в англійській мові. Чорний, білий та червоний кольори мають найбільше символьних значень у двох мовах, в англійській мові до них також долучається синій (блакитний, голубий).

Перспективою подальших розвідок у даному напрямку може стати порівняльний лінгвокогнітивний аналіз на матеріалі інших мов.

\section{ЛІТЕРАТУРА}

1. Бабій І.М. Семантика, структура та стилістичні функції назв кольорів у сучасній українській мові : автореф. дис. ... канд. філол. наук : 10.02.01 «Українська мова». Київ, 1997. 21 с.

2. Голубовська І.О. Етнічні особливості мовних картин світу : монографія. 2-ге вид., випр. і доп. Київ : Логос, 2004. 284 с.

3. Голубь Л.А. Сквозные мотивы языковой картины мира (на примере семантического поля «цвет» в английском и русском языках) : автореф. дис. ... канд. филол. наук : 10.02 .20 «Сравнительно-историческое, типологическое и сопоставительное языкознание». Москва, 2006. 25 с.

4. Деменчук О.В. Колоративна композита у мовній картині світу української та англійської націй: досвід когнітивно-ономасіологічного аналізу. Проблеми зіставної семантики : зб. наук. статей / відп. ред. М.П. Кочерган. Київ : Київський державний лінгвістичний ун-т, 2001. Вип. 5. С. 85- 89.

5. Деменчук О.В. Колоративна композита в англійській мові: когнітивно-ономасіологічний аспект : дис. ... канд. філол. наук : 10.02.04 «Германські мови». Київ, 2003. 240 с.

6. Дзивак О.Н. Лексика на обозначение цвета в современном украинском языке : автореф. дис. ... канд. филол. наук : 10.02.02 «Украинский язык». Киев, 1974. 34 с.

7. Дзівак О.М. Про систему назв кольорів у сучасній українській літературній мові. Украйнське мовознавство. 1975. Вип. 3. С. 23-31.

8. Жаботинская С.А. Ономасиологические модели и событийные схемы. Вісник Харківського національного університету ім. В.Н. Каразіна. 2009. № 837. С. 3-14.

9. Жаботинская С.А. Лингвокогнитивный подход к анализу номинативных процессов. Вісник Харківського національного університету ім. В.Н. Каразіна. 2010. Вип. 928. С. 6-20.

10. Жаботинская С.А. Генеративизм, когнитивизм и Семантика лингвальных сетей. Doctrina multiplex, veritas una. Учень багато, істина одна : зб. праць до ювілею Ізабелли Рафаїлівни Буніятової. Київ : Київський ун-т ім. Б. Грінченка, 2018. С. 99-141.

11. Жирмунская М.Л. Словообразовательные потенции прилагательных цветообозначения в современных германских языках : автореф. дисс. ... канд. филол. наук : 10.02 .04 «Германские языки». Москва, 1982. 25 с.

12. Кириченко А.Г. До семантичної характеристики назв кольорів у східнослов’ янських мовах. Питання украӥнського мовознавства. Львів : Вид-во Львівського ун-ту, 1960. Кн. 4. С. 127-136.

13. Ковальова Т.В. Лексико-семантичні поля колоративів в українській поезії початку ХХ ст. : автореф. дис. ... канд. филол. наук : 10.02.01 «Українська мова». Харків, 1999. 19 с.

14. Критенко А.П. Семантична структура назв кольорів в українській мові. Мовознавство. 1967. C. $97-112$.

15. Мелько Х.Б. Колоративна композита в англійській та українській мовах: особливості номінації. Науковий вісник ДДПУ імені І. Франка. Серія «Філологічні науки». Мовознавство. 2015. № 3. C. $153-160$.

16. Свецинська (Філатова) К.О. Шляхи та чинники формування колірного концепту на матеріалі англійської, української та новогрецької мов. Актуальні проблеми науки та освіти : зб. матер. XIII підсумк. наук.-практ. конф. викл. МДУ, Маріуполь, 4 лютого 2011 р. / ред. К.В. Балабанов. Маріуполь : МДУ, 2011. С. 314-316.

17. Філатова К.О. Кольороконцепти в номінативних моделях англійських, українських і новогрецьких композитів: лінгвокогнітивний аспект : дис. ... канд. філол. наук : 10.02.15 «Загальне мовознавство». Київ, 2018. 356 с.

18. Філатова К.О. Кольороконцепти в номінативних моделях англійських композитів: лінгвокогнітивний аналіз. Науковий вісник Дрогобищького державного педагогічного ун-ту ім. Івана Франка. Серія: філологічні науки (мовознавство) : зб. наук. праць. 2018. № 10. С. 145-149. 
19. Філатова К.О. Лінгвокогнітивний аналіз композитів із кольороназвами в українській мові. Науковий журнал ДВНЗ «Ужсородський національний університет» «Закарпатські філологічні студї». Серія: філологічні науки : зб. наук. праць. 2019. Вип. 12. С. 180-186.

20. Філатова К.О. Методика лінгвокогнітивного аналізу композитів із кольороназвами неблизькоспоріднених мов : тези Міжнар. науково-техн. конф. «Університетська наука-2020» (Маріуполь, 20-21 травня 2020 р.) : в 4 т. ; ДВНЗ «ПДТУ». Маріуполь : ПДТУ, 2020. С. 94-95.

21. Флойд Л.А. Лінгвоментальна специфіка непрямих назв кольорів (на матеріалі іспанської, англійської, української, російської мов) : дис. ... канд. філол. наук : 10.02.15 «Загальне мовознавство». Одеса, 2013. 187 с.

22. Berlin B., Kay P. Basic colour terms: their universality and evolution. Berkeley : Reed, 1969.178 p.

23. Birren F. Color and Human Response. New York : Van Nostrand Reinhold Co., 1978. 141 p.

24. Casson R.W. Color shift: evolution of English color terms from brightness to hue. Color Categories in Thought and Language / eds. C.L. Hardin, L. Maffi. Cambridge : Cambridge University Press, 1997. P. 224-239.

25. Gage J. Colour and culture: practice and meaning from antiquity to abstraction. Berkeley : University of California Press, 1999. 336 p.

26. Heider E.R. Universals in color naming and memory. Journal of Experimental Psychology. Washington, 1972. № 93 (1). P. 10-20.

27. Wierzbicka A. The semantics of colour: A new paradigm. Progress in Colour Studies ; eds. C.P. Biggam, C.J. Kay. Amsterdam : John Benjamins Publishing Company, 2006. P. 1-24.

28. Wittgenstein L. Remarks on Colour / eds. G.E.M. Anscombe ; trans. L. McAlister, M. Schättle. Oxford : Basil Blackwell, 1977. 170 p.

\section{REFERENCES}

1. Babii I. M. (1997) Semantyka, struktura ta stylistychni funktsii nazv koloriv u suchasniy ukrainskiy movi [Semantics, structure and stylistic functions of color-terms in modern Ukrainian language] (PhD Thesis), Kyiv: Institute of Ukrainian Language of the National Academy of Sciences of Ukraine.

2. Holubovska I. O. (2004) Etnichni osoblyvosti movnykh kartyn svitu [Ethnic features of linguistic models of the world]. Kyiv: Lohos. (in Ukrainian)

3. Golub L. A. (2006) Skvoznye motivy iazykovoy kartiny mira (na primere semanticheskogo polia "tsvet" $\mathrm{v}$ angliiskom i ukrainskom iazykakh) [Thorough motives of the linguistic model of the world (on the example of the semantic field "color" in English and Russian)] (PhD Thesis), Moscow: Moscow State Regional University.

4. Demenchuk O. V. (2001) Koloratyvna kompozyta u movniy kartyni svitu ukrainskoi ta anhliyskoi natsii: dosvid kohnityvno-onomasiolohichnoho analizu [Colorative compound in the linguistic model of the world of Ukrainian and English nations: cognitive-onomasiological analysis]. Problems of comparative semantics, vol. 5, pp. $85-89$.

5. Demenchuk O. V. (2003) Koloratyvna kompozyta v anhliiskiy movi: kohnityvno- onomasiolohichnyi aspekt [Colorative compound in English: cognitive-onomasiological aspect] (PhD Thesis), Kyiv : Kyiv National Linguistic University.

6. Dzivak O. N. (1974) Leksika na oboznachenie tsveta v sovremennom ukrainskom iazyke [Lexicon for nomination color-terms in modern Ukrainian language] ( $\mathrm{PhD}$ Thesis), Kiev.

7. Dzivak O. M. (1975) Pro systemu nazv koloriv u suchasniy ukrainskiy literaturniy movi [The system of color names in the modern Ukrainian literary language]. Ukrainian Linguistics, vol. 3, pp. 23-31.

8. Zhabotinskaya S. A. (2009) Onomasiologicheskie modeli i sobytiynye skhemy [Onomasiological models and propositional schemes]. V. N. Karazin Kharkiv National University Bulletin, no. 837, pp. 3-14.

9. Zhabotinskaya S. A. (2010) Lingvokognitivnyi podkhod k analizu nominativnykh protsessov [Cognitive linguistic approach to the analysis of nominative processes]. V. N. Karazin Kharkiv National University Bulletin, vol. 928, pp. 6-20.

10. Zhabotinskaya S. A. (2018) Generativizm, kognitivizm i Semantika lingvalnykh setey [Generativism, Cognitivism, and the Semantics of Lingual Networks]. Doctrina multiplex, veritas una. Uchen bahato, istyna odna, pp. 99-141.

11. Zhirmunskaya M. L. (1982) Slovoobrazovatelnye potentsii prilagatelnykh tsvetooboznacheniya v sovremennykh germanskikh yazykakh [Derivative potencies of color-nomination adjectives in Modern Germanic languages] (PhD Thesis), Moskva.

12. Kyrychenko A. H. (1960) Do semantychnoi kharakterystyky nazv koloriv u skhidnoslovianskykh movakh [Semantic characteristics of color names in East Slavic languages]. Ukrainian linguistics issues, no. 4, pp. 127-136. 
13. Kovalova T. V. (1999) Leksyko-semantychni polia koloratyviv v ukrainskiy poezii na pochatku XX st. [Lexico-semantic fields of the coloratives in Ukrainian poetry of the beginning of the 20th century] (PhD Thesis), Kharkiv: G. S. Scovoroda Kharkiv State Pedagogical University.

14. Krytenko A. P. (1967) Semantychna struktura nazv koloriv v ukrainskiy movi [Semantic structure of color names in Ukrainian language]. Linguistics, no. 4, pp. 97-112.

15. Melko Kh. B. (2015) Koloratyvna kompozyta $\mathrm{v}$ angliiskiy ta ukrainskiy movakh: osoblyvosti nominatsii [Colorative compound in English and Ukrainian: peculiarities of the nomination]. I. Franko Drohobych State Pedagogical University Bulletin (Linguistics), no. 3, pp. 153-60.

16. Svetsynska (Filatova) K. O. (2011) Shliakhy ta chynnyky formuvannia kolirnoho kontsepta na materiali angliiskoi, ukrainskoi ta novohretskoi mov [Ways and factors of color concept formation in English, Ukrainian and Modern Greek languages]. Proceedings of the Aktualni problemy nauky ta osvity: XIII pidsumkova naukovo-praktychna konferentsia vykladachiv (Ukraine, Mariupol, February 4, 2011) (eds. Balabanov K. V.), Mariupol: Mariupol State University, pp. 314-316.

17. Filatova K. O. (2018) Kolorokontsepty $\mathrm{v}$ nominativnykh modeliakh anhliiskykh, ukrainskykh i novohretskykh komposytiv: linhvokohnityvnyi aspect [Color-concepts in naming models of English, Ukrainian and Modern Greek compounds: a cognitive linguistic aspect] (PhD Thesis), Kyiv: Borys Hrinchenko Kyiv University.

18. Filatova K. O. (2018) Kolorokontsepty v nominatyvnykh modeliakh anhliiskykh kompozytiv: linhvokohnityvnyi analiz [Color-concepts in naming models of English compounds: a cognitive linguistic analysis]. I. Franko Drohobych State Pedagogical University Bulletin (Linguistics), no. 10, pp. 145-149.

19. Filatova K.O. (2019) Linhvokohnityvnyi analiz kompozytiv iz koloronazvamy v ukrainskii movi [Cognitive linguistic analysis of compounds with color-terms in Ukrainian]. Transcarpathian philological studies, vol. 12, pp. 180-186.

20. Filatova K. O. (2020) Metodyka linhvokohnityvnoho analizu kompozytiv iz koloronazvamy neblyzkosporidnenykh mov [Methodology of cognitive linguistic analysis of compounds with colorterms of non-cognate languages]. Proceedings of the Universytetska nauka-2020: mizhnarodna naukovotekhnichna konferentsia (Ukraine, Mariupol, May 20-21, 2020), Mariupol: Pryazovskyi State Technical University, pp. 94-95.

21. Floid L. A. (2013) Linhvomentalna spetsyfika nepriamykh nazv koloriv (na materiali ispanskoi, anhliiskoi, ukrainskoi, rosiiskoi mov) [Mental linguistic specificity of indirect color names (on the material of Spanish, English, Ukrainian, Russian languages] (PhD Thesis), Odesa: K. D. Ushynskyi South Ukrainian National Pedagogical University.

22. Berlin B., Kay P. (1969) Basic colour terms: their universality and evolution. Berkeley: Reed.

23. Birren F. (1978) Color and Human Response. New York: Van Nostrand Reinhold Co.

24. Casson R. W. (1997) Color shift: evolution of English color terms from brightness to hue. Color Categories in Thought and Language, pp. 224-239.

25. Gage J. (1999) Colour and culture: practice and meaning from antiquity to abstraction. Berkeley: University of California Press.

26. Heider E. R. (1972) Universals in color naming and memory. Journal of Experimental Psychology, no. 93(1), pp. 10-20.

27. Wierzbicka A. (2006) The semantics of colour: A new paradigm. Progress in Colour Studies, pp. 1-24.

28. Wittgenstein L. (1977) Remarks on Colour. Oxford: Basil Blackwell. 